\title{
Combined Effects of Growth Cycle and Different Levels of Aeration in Nutrient Solution on Productivity, Quality, and Shelf Life of Watercress (Nasturtium officinale R. Br.) Plants
}

\author{
Diana Niñirola, Juan A. Fernández, Encarnación Conesa, \\ and Juan A. Martínez \\ Producción Vegetal, E.T.S. Ingeniería Agronómica, Universidad Politécnica \\ de Cartagena, C/Paseo Alfonso XIII 48, 30203 Cartagena, Spain
}

\section{Catalina Egea-Gilabert ${ }^{1}$}

Ciencia y Tecnología Agraria, E.T.S. Ingeniería Agronómica, Universidad Politécnica de Cartagena, C/Paseo Alfonso XIII 48, 30203 Cartagena, Spain

Additional index words. dissolved oxygen, floating system, fresh-cut vegetables, root hypoxia

\begin{abstract}
The objective of this research was to study the effects of growing cycle (spring vs. winter) and nutrient solution aeration [no aeration (NA), low aeration (LA) or high aeration (HA)] on yield, quality, and on shelf life as a fresh-cut product of watercress grown in a floating system. The growing cycles lasted 25 days in spring and 39 days in winter. In the spring cycle, the plants had significantly higher yield and antioxidant capacity and lower specific leaf area, total root length, root diameter, length of 0 to $0.5 \mathrm{~mm}$ diameter root, and oxalate content than in the winter cycle. The absence of aeration increased the antioxidant capacity and vitamin $C$ content in both cycles. Several adventitious roots developed exogenously from the watercress stem at the nodes as a morphological adaptation to oxygen depletion, particularly in NA conditions. The nitrate, oxalate, $\mathrm{Ca}^{2+}, \mathrm{K}^{+}$contents, and microbial populations were affected by both the cycle and the aeration conditions. Hue angle of the leaves was affected by both the cycle and storage time, and chromaticity and lightness were affected by the three factors (cycle, aeration, and storage time). The global quality was significantly higher ( 7.8 over 9 points hedonic scale) in the spring cycle than in winter, the score reflecting their marketable value (7.0 over 9 points). The mild dehydration problems observed in the winter cycle that led to a slightly lower overall product quality that could be the result of the development of thinner leaves and also the differences in the respiration rates compared with the spring cycle. In general, the spring cycle led to higher productivity, antioxidant capacity, and $\mathrm{Ca}^{2+}$ and $\mathrm{K}^{+}$contents and lower oxalate content. Aeration slightly affected the quality of the final product, the plants grown in non-aerated conditions being richer in vitamin $C$ and antioxidants and with lower nitrate content.
\end{abstract}

Nowadays, there is a high demand for fresh-cut vegetables as a result of the consumer's desire for healthy, convenient, fresh, and ready-to-eat commodities. Consequently, there is a much larger variety of salad leaves on the market than was the case quite recently. They include watercress [Rorippa nasturtium-aquaticum (L.) Hayek = Nasturtium officinale $\mathrm{R}$. Br.], alone or mixed with another leafy vegetable. Watercress is native

Received for publication 16 Jan. 2014. Accepted for publication 15 Mar. 2014

This work has been financed by the Spanish project MICINN-FEDER AGL2010-17680. The work was partially carried out in the Instituto de Biotecnología Vegetal (IBV) of Universidad Politécnica de Cartagena (Spain).

We thank Dr. Silvana Nicola for helpful review of the manuscript.

${ }^{1}$ To whom reprint requests should be addressed; e-mail catalina.egea@upct.es. from Europe to central Asia and is one of the oldest of the leafy vegetables known to be consumed by humans. Currently in the fresh salads industry, watercress is regarded as a valuable food product, being recognized for its high content of health-promoting compounds such as antioxidants and phenolic compounds (Martínez-Sánchez et al., 2008). It is known to contain one of the highest concentrations of the beneficial antioxidant, phenethyl isothiocyanate, which has been shown to increase the body's potential to resist certain carcinogenic agents (Palaniswamy et al., 1997; Syed Alwi et al., 2010).

Watercress grows wild in streams, ponds, and reservoirs. Taking advantage of the fact that it is a semiaquatic plant, watercress can be grown in hydroponic cultivation. Among such hydroponic methods, the floating system is one of the most suitable for growing leafy vegetables, because plants can be grown at high densities, thereby producing high yields in a short time, whereas the resulting product is clean and very suitable to be processed as a ready-to-eat vegetable. Like in other hydroponic systems, plants growing in a floating system may suffer hypoxia because the roots gradually consume the oxygen dissolved in the nutrient solution. Therefore, a suitable concentration of oxygen in the root environment is necessary to ensure the functionality of the root, because a lack of oxygen reduces water and mineral uptake by the plant, which may limit growth and, consequently, crop yield (Tesi et al., 2003a). To avoid negative repercussions on yield, growers aerate the nutrient solution to enrich it with oxygen. There are, however, significant differences in sensitivity to oxygen deficiency in the rooting medium among plant species, even among cultivars (Visser et al., 2000). This is because in some plants, the low oxygen concentrations can lead to anatomical and morphological adaptations that facilitate the transport of oxygen from the shoot to the roots. For example, some plants create aerenchyma, a specialized tissue in the roots that consists of longitudinal gas-filled channels that facilitate the internal diffusion of gases (Evans, 2003). Another developmental adaptation to depleted oxygen is the presence of adventitious roots, which often contain extensive aerenchymatous tissue and are thus less affected by hypoxia conditions (Visser et al., 1997). In watercress, adventitious roots are produced in the leaf axils and are exogenous in origin (Kaskey and Tindall, 1979). Watercress plants growing in no aeration conditions may promote the formation and growth of new adventitious roots to adapt to the mentioned conditions.

The quality of the final product can be affected by metabolic adaptations to oxygen deficiency, reducing the potential accumulation of antinutritional end compounds and improving, in many cases, the concentrations of functional phytochemicals. In general, a lack of aeration in the nutrient solution has been seen to decrease shoot nitrate concentrations (Ferrante et al., 2003; Tesi et al., 2003b) and increase the concentrations of functional phytochemicals in several leafy species (Lara et al., 2011).

The quality of the raw material is essential to ensure the quality of fresh-cut products during storage (Bonasia et al., 2013). Although the horticultural literature contains numerous reports describing effects of preharvest factors on postharvest quality of fruits and vegetables (Mattheis and Fellman, 1999), too little attention has been paid to the effects of preharvest factors on the shelf life of baby leaf vegetables. It is well known that cultivation conditions such as the culture system, irrigation, climate, and fertilization influence the quality of the raw material and therefore can modify its physiological behavior and suitability for fresh-cut processing (Nicola et al., 2009). In particular, the quality of processed baby leaf spinach was slightly affected by growing cycle conditions (Conte et al., 2008). It is highly likely that leaves with improved quality will be more able to 
withstand the rigorous processing that includes harvest, transportation, washing, sanitization, dewatering, and packaging (Clarkson et al., 2003). Besides, any preharvest condition that stresses a plant such as the non-aeration of the nutrient solution could affect the quality and shelf life of the final product. For example, in purslane grown in a floating system, it was demonstrated that aeration treatments did not significantly affect the gas changes pattern within packages, although shoots cultivated without aeration showed a slightly lower total antioxidant capacity during their shelf life (Rodríguez-Hidalgo et al., 2010a).

The objective of this research was to study the effects of growing cycle and nutrient solution aeration and the combination of both factors on yield, quality, and on shelf life as a fresh-cut product of watercress grown in a floating system.

\section{Material and Methods}

Plant material and growing conditions. The experiments were conducted at the "Tomás Ferro" Experimental Agro-Food Station, Technical University of Cartagena (UPCT; lat. $37^{\circ} 41^{\prime} \mathrm{N}$; long. $0^{\circ} 57^{\prime} \mathrm{W}$ ). The commercial cultivar of watercress (Nasturtium officinale $\mathrm{R}$. Br.) "Large leaf" (Tozer Seeds Co., Cobham, U.K.) was cultivated in a floating system in an unheated greenhouse covered with thermal polyethylene. Two crop cycles were carried out with sowings on 18 Apr. 2011 (spring cycle) and 2 Dec. 2011 (winter cycle). "Styrofloat" trays of $60 \mathrm{~cm} \times$ $41 \mathrm{~cm}$ were used in the trials. These trays have pyramidal-trunk 172-mm long fissures $20 \mathrm{~mm}$ apart and grouped in three for a total of 42 fissures per tray; fissures measure $10 \mathrm{~mm}$ on the top and $2.5 \mathrm{~mm}$ on the bottom, leading to a volume of $32.4 \mathrm{~cm}^{3}$ per fissure. Sowing was carried out manually into "styrofloat" trays containing peat, which were then transferred to flotation beds, floating on fresh tap water with an electrical conductivity (EC) of $1.1 \mathrm{dS} \cdot \mathrm{m}^{-1}$ and a $\mathrm{pH}$ of 7.8 . After transferring the trays to flotation beds, aeration was provided at three levels using a blow pump connected to a pipe trellis positioned at the bottom of each flotation bed. The pipes were perforated with holes at 0,6 , or 36 holes $/ \mathrm{m}^{2}$ to provide the different levels of aeration: NA, LA, or HA (Lara et al., 2011). Each level of treatment was carried out in $135 \mathrm{~cm} \times$ $125 \mathrm{~cm} \times 20-\mathrm{cm}$ beds located at three places inside a greenhouse for all the experiments. Each bed had four floating trays of $60 \mathrm{~cm} \times$ $41 \mathrm{~cm}$.

A week after sowing, the tap water in the beds was replaced with a nutrient solution (Egea-Gilabert et al., 2009). A week after transferring to the floating beds, the plants were thinned, leaving 12 plants per fissure (2050 plants $/ \mathrm{m}^{2}$ ). The EC and temperature of the nutrient solution were monitored during the growing cycles using Campbell CS547 sensors (Campbell Scientific Inc., Logan, UT) and the oxygen concentrations were monitored using Campbell CS512 sensors located in each flotation bed. The temperature and light conditions during the experiments were as follows: spring cycle, minimum, average, and maximum air temperatures of 14.6, 27.9, and $36.5^{\circ} \mathrm{C}$, respectively, and an average daily light integral (DLI) of $20.51 \mathrm{~mol} \cdot \mathrm{m}^{-2} \cdot \mathrm{s}^{-1}$; winter cycle, minimum, average, and maximum air temperatures of $11.7,15.2$, and $18.7^{\circ} \mathrm{C}$, and an average DLI of $6.58 \mathrm{~mol} \cdot \mathrm{m}^{-2} \cdot \mathrm{s}^{-1}$.

Harvesting was carried out at the same phenological stage for both cycles, that is, when seven to eight leaves had been formed on each plant. This occurred $25 \mathrm{~d}$ after sowing in spring and $39 \mathrm{~d}$ in winter. Fortyeight plants from four fissures randomly chosen from each tray were harvested for each treatment. The plants were divided randomly into two sets, one for harvest analysis and one for postharvest analysis.

Analysis at harvesting time. Dry matter content (\%) of shoots, specific leaf area (SLA), leaf color, root growth, and number of adventitious roots developing exogenously from the stem at the nodes were measured. Leaf area was measured with a leaf area meter (LICOR-3100 C; LICOR Biosciences Inc., Lincoln, NE). The color parameters in leaves were determined using a tristimulus colorimeter ( $\mathrm{L}^{*} \mathrm{a}^{*} \mathrm{~b}^{*}$ color space) (Minolta CR-10; Konica- Minolta Sensing Inc., Osaka, Japan) and calculating the hue angle $=\arctan$ $\left(\mathrm{b}^{*} / \mathrm{a}^{*}\right)$ and chromaticity $\left(\mathrm{C}^{*}\right)=\left[\left(\mathrm{a}^{*}\right)^{2}+\right.$ $\left.\left(b^{*}\right)^{2}\right]^{1 / 2}$. Total root length and diameter were determined with a Winrhizo LA 1600 root counter (Regent Inc., Quebec, Canada). The dry matter contents were determined by drying in an oven at $50{ }^{\circ} \mathrm{C}$ until constant weight was reached. In addition, the total production (yield) was calculated.

After harvesting of the spring cycle plants, root sections were obtained from taproots $1.0 \mathrm{~cm}$ from the root collar. Fresh sections were fixed, dehydrated, stained, embedded using a JB4 Plus Embedding Kit (Electron Microscopy Sciences, Hatfield, PA), and observed by optical microscopy to calculate the percentage of aerenchyma tissue (Lara et al., 2011).

At both harvesting times, the following biochemical parameters were analyzed: nitrate, oxalate, potassium, and calcium contents were extracted in triplicate by using $0.2 \mathrm{~g}$ of shoot dry samples per each treatment and quantified by ion chromatography (Lara et al., 2011). The total phenolic content was determined by the Folin-Ciocalteu colorimetric method (Tarazona-Díaz et al., 2011). The antioxidant capacity was evaluated in terms of their free radical-scavenging capacity (Brand-Williams et al., 1995). The content of vitamin C, measured as ascorbic acid (AA) and dehydroascorbic acid, was measured in shoots using high-performance liquid chromatography (Shimadzu Corporation, Canby, OR) equipped with a degasser, DGU-20A, autosampler SIL-30AC, column oven CTO$10 \mathrm{AS}$, communications module CMB-20A, and diode array detector SPDM-20 (RodríguezHidalgo et al., 2010b).

Postharvest product management and analysis. Harvested plants were placed in plastic bags and immediately transported 6 $\mathrm{km}$ in a portable box with ice to the Instituto de Biotecnología Vegetal of the UPCT where they were stored for $4 \mathrm{~h}$ at $5{ }^{\circ} \mathrm{C}$. Then, in a disinfected cold room at $10{ }^{\circ} \mathrm{C}$, all shoots free from defects were disinfected by washing for 2 min with a solution containing 100 ppm NaOCl (Panreac, Barcelona, Spain) and $0.2 \mathrm{~g} \cdot \mathrm{L}^{-1}$ citric acid $(\mathrm{pH} 6.5)$ at $5^{\circ} \mathrm{C}$. The shoots were then rinsed for 2 min under tap water to eliminate chlorine residues. Excess surface water was removed by using a handheld salad spinner for $30 \mathrm{~s}$. Then, $20 \mathrm{~g}$ of shoots were placed in polypropylene (PP) baskets of 1-L capacity, the top of which were thermosealed with a $34-\mu \mathrm{m}$ thick film composed of polyethylene terephthalate (PET) + oriented polypropylene (OPP) and stored at $5{ }^{\circ} \mathrm{C}$ for $7 \mathrm{~d} . \mathrm{O}_{2}$ transmission was 1.0 to 1.2 $\left[\mathrm{mL}\left(\mathrm{m}^{2} 24 \mathrm{~h} \mathrm{~atm}\right)^{-1}\right]$ measured at $23{ }^{\circ} \mathrm{C}$ and $0 \%$ relative humidity $(\mathrm{RH})$, and water vapor transmission was $\left.1.3\left[\mathrm{~mL}^{2} 24 \mathrm{~h} \mathrm{~atm}\right)^{-1}\right]$ at $38^{\circ} \mathrm{C}$ and $100 \%$ RH. Permeation values were supplied by Plásticos del Segura (Murcia, Spain). The storage temperature was selected as the maximum limit recommended and most commonly used for fresh-cut vegetables during their commercial distribution and retail sale (Tomás-Callejas et al., 2011).

Microbial growth was assessed after processing. Samples of $10 \mathrm{~g}$ fresh weight (FW) from each treatment were blended with $90 \mathrm{~mL}$ of sterile tryptone phosphate water (Scharlab, Barcelona, Spain) at $\mathrm{pH} 7.0$ for $1 \mathrm{~min}$ in a sterile bag by using a stomacher. Serial dilutions were prepared in $9 \mathrm{~mL}$ tryptone phosphate water. From each dilution, 1-mL aliquots were aseptically pipetted for microbial population counting. Plate count agar (Scharlab) ( $\mathrm{pH} 7.0$ ) for both mesophilic aerobic microorganisms, incubated at $26^{\circ} \mathrm{C}$ for $3 \mathrm{~d}$, and psychrophilic microorganisms, incubated at $4{ }^{\circ} \mathrm{C}$ for $10 \mathrm{~d}$, were used. Duplicates were made for each dilution. Microbial counts were reported as $\log _{10}$ colony-forming units (CFU) per gram of FW.

Changes in $\mathrm{O}_{2}$ and $\mathrm{CO}_{2}$ partial pressures within the PP baskets were monitored daily throughout the shelf life. A $0.5-\mathrm{mL}$ sample of the headspace was withdrawn from the $\mathrm{PP}$ baskets with a gas-tight syringe and $\mathrm{O}_{2}$ and $\mathrm{CO}_{2}$ levels were determined by gas chromatography with a Perkin-Elmer apparatus (Norwalk, CT) equipped with a thermal conductivity detector (Tomás-Callejas et al., 2011). After $7 \mathrm{~d}$ at $5{ }^{\circ} \mathrm{C}$, microbial growth and leaf color were determined as described previously.

Sensory quality test. The sensory quality was evaluated in a tasting room after $7 \mathrm{~d}$ of cold storage by a test panel consisting of 11 people. Visual quality factors (overall visual quality and global quality) were scored on a 9 -point hedonic scale $(1=$ extremely poor, $3=$ poor, $5=$ acceptable and limit of usability, $7=$ good, and $9=$ excellent). Disorders (browning, visual dehydration, off-odors, off-color, and off-flavors) were scored according to the following scale of damage incidence and severity: $1=$ none, $2=$ slight, $3=$ moderate 
(limit of usability), $4=$ severe, $5=$ extreme (Tomás-Callejas et al., 2011).

Statistical analysis. A randomized complete block design with three replicates per level of aeration was used in the greenhouse in both growing seasons. Data were analyzed using Statgraphics Plus. Analysis of variance (three-way ANOVA) was performed in which levels of aeration (NA, LA, HA), growing seasons (spring and winter), and storage time ( 0 and $7 \mathrm{~d}$ ) were included. When the variables were measured at harvesting time, only two factors (aeration and growing season) were included. When interactions were significant they were included in the ANOVA, a least significant difference test was performed to compare level of aeration, growing seasons, and storage time.

\section{Results}

Temperature and dissolved oxygen in the nutrient solution. The aeration treatments did not affect the temperature of the nutrient solution in either cycle (Fig. 1). However, the different levels of aeration affected the quantity of dissolved oxygen (DO) in the nutrient solution. DO mean levels were 3.3, 5.8 , and $6.9 \mathrm{mg} \cdot \mathrm{L}^{-1}$ in $\mathrm{NA}, \mathrm{LA}$, and $\mathrm{HA}$ conditions, respectively, during the spring cycle and $8.4,9.0$, and $9.2 \mathrm{mg} \cdot \mathrm{L}^{-1}$ in NA, LA, and HA conditions, respectively, during the winter cycle. In the spring cycle, the decrease of aeration rapidly led to lower levels of DO than in the winter cycle as a result of the higher temperatures of the nutrient solution. The level of DO in the NA conditions fell from $6.5 \mathrm{mg} \cdot \mathrm{L}^{-1}$ to $3.1 \mathrm{mg} \cdot \mathrm{L}^{-1}$ in the spring cycle and hardly decreased in the winter cycle (from $8.4 \mathrm{mg} \cdot \mathrm{L}^{-1}$ to 8.1 $\left.\mathrm{mg} \cdot \mathrm{L}^{-1}\right)$.

Growth, yield, and quality characteristics of watercress at harvesting time. There were significant differences for SLA, yield, total root length, root diameter, and length of 0 to $0.5 \mathrm{~mm}$ diameter root for the cycle, but not for the aeration factor (Table 1). In addition, the dry matter content was not affected by the cycle or by the aeration conditions. There was no statistically significant interaction between cycle and aeration for any growth parameter. The yield was $20 \%$ higher in the spring cycle but SLA was 26\% lower than in the winter cycle (Table 1). In the winter cycle, the root was thinner and longer as a result of the greater length of fine roots ( 0 to $0.5 \mathrm{~mm}$ in diameter).

The anatomical root study in the spring cycle demonstrated that the low oxygen concentrations led to some morphological adaptations such as the development of aerenchyma tissue in the roots and the presence of adventitious roots. The aerenchyma occupied a low percentage of root section $(2 \%$ or less in NA, $0.8 \%$ or less in LA, and $0.3 \%$ or less in HA conditions). On the other hand, watercress had several adventitious roots developing exogenously from the stem at the nodes, significantly higher in NA than in LA and HA conditions (mean values per plant: 4.5, 2.6, and 2.8 in NA, LA, and HA conditions, respectively), and some of those roots were able to grow into the media. In addition, the number of nodes with adventitious roots longer than $2 \mathrm{~mm}$ was significantly higher in NA conditions than in the aerated conditions (mean values per plant: $1.7,0.8$, and 0.8 in NA, LA, and HA conditions, respectively).

ANOVA showed that aeration conditions had a statistically significant effect on antioxidant capacity, vitamin $\mathrm{C}$, nitrate, and $\mathrm{Ca}^{2+}$ contents (Table 2). Statistical analysis showed a significant interaction between both factors for nitrate, oxalate, $\mathrm{Ca}^{2+}$, and $\mathrm{K}^{+}$contents, whereas no significant interaction was observed for total phenolics, antioxidant capacity, or vitamin $\mathrm{C}$. In addition, the total phenolic contents were not affected by the cycle or by the aeration conditions.

Aeration reduced the antioxidant capacity in both cycles, the highest values being obtained in the spring cycle (Table 2 ). The vitamin $\mathrm{C}$ content was significantly higher in
NA conditions in the spring cycle and also higher than in the winter cycle. The nitrate content was lowest in the NA condition in the winter cycle, whereas there were no differences in the nitrate contents among the different levels of aeration in the spring cycle. The oxalate content was lower in the spring cycle, particularly in the aerated treatments. The $\mathrm{Ca}^{2+}$ content was higher in the spring cycle and its content increased in the winter cycle with aeration treatments. Finally, the $\mathrm{K}^{+}$content was also increased by aeration in the winter cycle, whereas there were no differences between levels of aeration in the spring cycle.

Visual and microbiological quality of fresh-cut product. Both microbial populations (mesophilic and psychrophilic microorganisms) were affected by the cycle and storage time (Table 3). The mesophilic microorganisms were also affected by the aeration treatments. The interaction between aeration treatment and cycle was significant for both microbial populations. The microbial load for mesophilic microorganisms was significantly lower in the winter cycle NA conditions than in the spring cycle NA and LA conditions (Fig. 2A). In addition, the microbial charge of psychrophilic microorganisms in NA and LA conditions in winter was lower than in any aeration treatment in the spring cycle (Fig. 2B). The interaction between aeration treatment and storage time was significant only for psychrophilic microorganisms (Table 3), being significantly lower in NA conditions at Day 0 than in any aeration treatment at Day 7 (Fig. 2C).

The ANOVA of the color parameters showed that hue angle and $\mathrm{C}^{*}$ were affected by both cycle and storage time and $\mathrm{L}^{*}$ only by storage time (Table 3 ). The aeration treatment had no effect on any of the measured parameters. The interaction of the three factors was significant for $\mathrm{C}^{*}$ and $\mathrm{L}^{*}$. The percentage of variance explanation was very low as a result of the high residual value obtained ( $\approx 43 \%$ and $64 \%$, respectively). $\mathrm{C}^{*}$
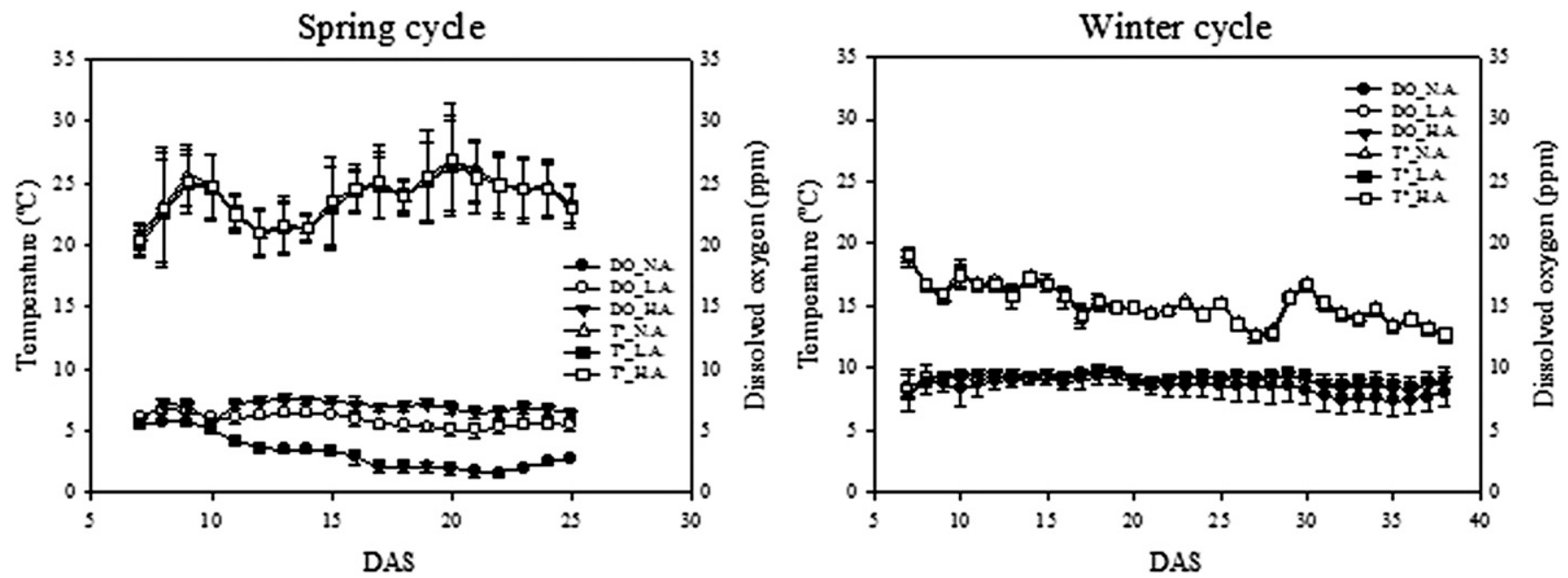

Fig. 1. Evolution of dissolved oxygen (DO) and temperature ( $\mathrm{T}^{\mathrm{a}}$ ) of the nutrient solution under different levels of aeration-no aeration (NA), low aeration (LA), high aeration (HA) - in two different crop cycles. Each datum point for each day after sowing (DAS) is the average of 24 hourly measurements $(\mathrm{n}=3)$. 
Table 1. Influence of aeration of the nutrient solution - no aeration (NA), low aeration (LA), high aeration (HA) — at harvest on the growth parameters [specific leaf area (SLA), dry matter content, yield, total root length, root diameter, length of 0 to 0.5 diameter root] of watercress cultivated in spring and winter cycles in a floating system.

\begin{tabular}{|c|c|c|c|c|c|c|c|}
\hline Cycle (A) & Aeration (B) & $\begin{array}{c}\text { SLA } \\
\left(\mathrm{m}^{2} \cdot \mathrm{kg}^{-1}\right)\end{array}$ & $\begin{array}{c}\text { Dry matter content } \\
(\%)\end{array}$ & $\begin{array}{c}\text { Yield } \\
\left(\mathrm{kg} \cdot \mathrm{m}^{-2}\right)\end{array}$ & $\begin{array}{l}\text { Total root length } \\
(\mathrm{cm})\end{array}$ & $\begin{array}{l}\text { Root diam } \\
\quad(\mathrm{mm})\end{array}$ & $\begin{array}{c}\text { Length of } 0 \text { to } 0.5 \text { diam } \\
\text { root }(\mathrm{mm})\end{array}$ \\
\hline Spring & & $0.73 \mathrm{a}^{\mathrm{z}}$ & 4.72 & $3.48 \mathrm{~b}$ & $70.77 \mathrm{a}$ & $0.20 \mathrm{a}$ & $44.03 \mathrm{a}$ \\
\hline \multirow[t]{7}{*}{ Winter } & & $0.99 \mathrm{~b}$ & 4.45 & $2.99 \mathrm{a}$ & $195.40 \mathrm{~b}$ & $1.11 \mathrm{~b}$ & $188.70 \mathrm{~b}$ \\
\hline & NA & 0.85 & 4.77 & 3.06 & 137.29 & 0.66 & 119.74 \\
\hline & LA & 0.85 & 4.58 & 3.36 & 135.70 & 0.67 & 118.31 \\
\hline & HA & 0.89 & 4.41 & 3.28 & 126.25 & 0.65 & 111.03 \\
\hline & & $* * * y$ & $* * *$ & $* * *$ & $* * *$ & $* * *$ & $* * *$ \\
\hline & & NS & NS & NS & NS & NS & NS \\
\hline & & NS & NS & NS & NS & NS & NS \\
\hline
\end{tabular}

${ }^{\mathrm{z}}$ Values within the same column followed by a different lower-case letter are significantly different (least significant difference test) at $P \leq 0.05$.

${ }^{\mathrm{y}}$ Asterisks indicate significances at $* P \leq 0.05 ; * * P \leq 0.01 ; * * * P \leq 0.001$; NS $=$ nonsignificant.

Table 2. Influence of aeration of the nutrient solution — no aeration (NA), low aeration (LA), high aeration (HA) — on the biochemical parameters at harvest (total phenolics, antioxidant capacity, vitamin $\mathrm{C}$, nitrate, oxalate, $\mathrm{Ca}^{2+}$ and $\mathrm{K}^{+}$contents) of watercress cultivated in spring and winter cycles in a floating system.

\begin{tabular}{|c|c|c|c|c|c|c|c|c|}
\hline Cycle (A) & Aeration (B) & $\begin{array}{l}\text { Total phenolics } \\
\text { (mg CAE/kg FW) }\end{array}$ & $\begin{array}{c}\text { Antioxidant capacity } \\
\text { (mg AAE/kg FW) }\end{array}$ & $\begin{array}{c}\text { Vitamin C } \\
\left(\mathrm{mg} \cdot \mathrm{kg}^{-1} \mathrm{FW}\right)\end{array}$ & $\begin{array}{c}\text { Nitrate } \\
\left(\mathrm{mg} \cdot \mathrm{kg}^{-1} \mathrm{FW}\right)\end{array}$ & $\begin{array}{c}\text { Oxalate } \\
\left(\mathrm{mg} \cdot \mathrm{kg}^{-1} \mathrm{FW}\right)\end{array}$ & $\begin{array}{c}\mathrm{Ca}^{2+} \\
\left(\mathrm{mg} \cdot \mathrm{kg}^{-1} \mathrm{FW}\right)\end{array}$ & $\begin{array}{c}\mathrm{K}^{+} \\
\left(\mathrm{mg} \cdot \mathrm{kg}^{-1} \mathrm{FW}\right)\end{array}$ \\
\hline Spring & & 47.3 & $849.9 b^{z}$ & 546.1 & 3933 & $28.1 \mathrm{a}$ & $1047.0 \mathrm{~b}$ & $4199.74 \mathrm{~b}$ \\
\hline \multirow[t]{4}{*}{ Winter } & & 43.4 & $506.6 \mathrm{a}$ & 544.2 & 4286 & $49.9 \mathrm{~b}$ & $653.5 \mathrm{a}$ & $3051.1 \mathrm{a}$ \\
\hline & NA & 43.6 & $809.9 \mathrm{~b}$ & $623.4 \mathrm{~b}$ & $3611 \mathrm{a}$ & 37.7 & $753.8 \mathrm{a}$ & 3396.4 \\
\hline & LA & 42.0 & $616.0 \mathrm{a}$ & $521.9 \mathrm{a}$ & $4307 \mathrm{~b}$ & 38.5 & $924.6 \mathrm{~b}$ & 3612.2 \\
\hline & HA & 50.6 & $608.8 \mathrm{a}$ & $517.1 \mathrm{a}$ & $4409 \mathrm{~b}$ & 40.8 & $872.4 \mathrm{~b}$ & 3813.6 \\
\hline \multirow[t]{3}{*}{ Spring } & NA & 47.5 & $972.7 \mathrm{~b}$ & $680.1 \mathrm{~b}$ & 3968 & $31.5 \mathrm{~b}$ & 1080.6 & 4550.2 \\
\hline & LA & 42.7 & $798.0 \mathrm{a}$ & $513.6 \mathrm{a}$ & 4024 & $26.6 \mathrm{a}$ & 1092.2 & 3997.6 \\
\hline & HA & 51.7 & $779.1 \mathrm{a}$ & $498.5 \mathrm{a}$ & 3805 & $26.2 \mathrm{a}$ & 968.3 & 4051.4 \\
\hline \multirow[t]{6}{*}{ Winter } & NA & 39.7 & $647.2 \mathrm{~b}$ & $566.7 \mathrm{~b}$ & $3252 \mathrm{a}$ & 44.1 & $427.1 \mathrm{a}$ & $2242.5 \mathrm{a}$ \\
\hline & LA & 41.3 & $434.1 \mathrm{a}$ & $530.3 \mathrm{a}$ & $4590 \mathrm{~b}$ & 55.0 & $756.9 \mathrm{~b}$ & $3226.9 \mathrm{~b}$ \\
\hline & HA & 49.4 & $438.6 \mathrm{a}$ & $535.7 \mathrm{a}$ & $5013 \mathrm{~b}$ & 50.7 & $776.6 \mathrm{~b}$ & $3575.9 \mathrm{~b}$ \\
\hline & A & NS & $* * * y$ & NS & NS & $* * *$ & $* * *$ & $* *$ \\
\hline & B & NS & $* *$ & $*$ & $*$ & NS & $*$ & NS \\
\hline & $\times \mathrm{B}$ & NS & NS & NS & $*$ & $*$ & $* *$ & $*$ \\
\hline
\end{tabular}

${ }^{\mathrm{z}}$ Values within the same column followed by a different lower-case letter are significantly different (least significant difference test) at $P \leq 0.05$.

${ }^{\mathrm{y}}$ Asterisk indicates significant differences between spring and winter cycles.

NS = nonsignificant.

$\mathrm{CAE}=$ chlorogenic acid equivalent; $\mathrm{FW}=$ fresh weight; $\mathrm{AAE}=$ ascorbic acid equivalent.

Table 3. Analysis of variance (in percentage of the total sum of squares and probability) of microbial growth (mesophilic and psychrophilic microorganisms) and leaf color parameters [hue angle, chromaticity $\left(\mathrm{C}^{*}\right)$ and lightness $\left.\left(\mathrm{L}^{*}\right)\right]$ of watercress either at harvest or $7 \mathrm{~d}$ at $5{ }^{\circ} \mathrm{C}$.

\begin{tabular}{|c|c|c|c|c|c|c|c|}
\hline Source of variation & $\mathrm{df}$ & $\begin{array}{c}\text { Mesophilic } \\
\text { microorganisms }\end{array}$ & $\begin{array}{l}\text { Psychrophilic } \\
\text { microorganisms }\end{array}$ & df & Hue angle & $\mathrm{C}^{*}$ & $\mathrm{~L}^{*}$ \\
\hline \multicolumn{8}{|l|}{ Main effects } \\
\hline Cycle (A) & 1 & $14.11 * * * z$ & $44.90 * * *$ & 1 & $4.85 * * *$ & $27.87 * * *$ & $0.73 \mathrm{NS}$ \\
\hline Storage time (B) & 1 & $11.10 * * *$ & $30.57 * * *$ & 1 & $30.72 * * *$ & $20.94 * * *$ & $2.20 * * *$ \\
\hline Aeration (C) & 2 & $4.50 *$ & $1.09 \mathrm{NS}$ & 2 & $1.16 \mathrm{NS}$ & $0.93 \mathrm{NS}$ & $1.11 \mathrm{NS}$ \\
\hline \multicolumn{8}{|l|}{ Interactions } \\
\hline $\mathrm{A} \times \mathrm{B}$ & 1 & $24.69 * * *$ & $0.12 \mathrm{NS}$ & 1 & $1.22 *$ & $5.09 * * *$ & $6.05 * * *$ \\
\hline $\mathrm{A} \times \mathrm{C}$ & 2 & $13.26 * * *$ & $3.49 *$ & 2 & $0.22 \mathrm{NS}$ & $2.03 \mathrm{NS}$ & $2.07 *$ \\
\hline $\mathrm{B} \times \mathrm{C}$ & 2 & $2.12 \mathrm{NS}$ & $3.59 *$ & 2 & $0.21 \mathrm{NS}$ & $0.03 \mathrm{NS}$ & $0.92 \mathrm{NS}$ \\
\hline $\mathrm{A} \times \mathrm{B} \times \mathrm{C}$ & 2 & $2.24 \mathrm{NS}$ & $0.53 \mathrm{NS}$ & 2 & $0.18 \mathrm{NS}$ & $1.24 *$ & $3.04 *$ \\
\hline Residual & 56 & 27.98 & 15.71 & 255 & 61.45 & 42.88 & 63.89 \\
\hline
\end{tabular}

${ }^{\mathrm{z}}$ Asterisks indicate significances at $* P \leq 0.05 ; * * P \leq 0.01 ; * * * P \leq 0.001$; Ns $=$ nonsignificant.

was significantly lower in spring than in winter and increased significantly with storage time (Table 4 ). In winter, $C^{*}$ increased significantly only in the HA treatments at Day 7 with respect to Day 0. At harvesting time, there were significant differences between spring and winter cycles only in NA conditions (Table 4). In general, L* was higher at Day 7 than at Day 0 in both cycles in all the aeration treatments.

The steady-state atmosphere within PP baskets was reached at the second day of storage in both crop cycles. No differences in $\mathrm{O}_{2}$ and $\mathrm{CO}_{2}$ levels were observed among aeration treatments during storage. Therefore, respiration rates were only affected by the crop cycle (Fig. 3). Hence, the $\mathrm{O}_{2}$ at equilibrium was lower in the shoots of watercress grown in winter $(\approx 15 \mathrm{kPa})$ than in watercress grown in spring, where the level of the same metabolic gas ranged from 17 to $19 \mathrm{kPa}$. In contrast, $\mathrm{CO}_{2}$ was quite similar in the two cycles, $\approx 3$ to $4 \mathrm{kPa}$ at equilibrium.

Cycle was the main factor that influenced the differences observed in visual quality and dehydration of watercress at the end of the storage, whereas the aeration did not affect any of the measured parameters. In general, dehydration was very low in both crop cycles although slightly higher in winter (1.23 and 1.76 over 5 points hedonic scale in the spring and winter cycles, respectively). The visual quality was significantly higher in the spring cycle ( 7.5 over 9 points hedonic scale) than in winter (6.7 over 9$)$. The global quality was significantly higher (7.8 over 9$)$ in the spring cycle than in winter $(7.0$ over 9$)$, the score reflecting their marketable value.

\section{Discussion}

Plant species tolerant to oxygen depletion in the root medium can develop morphological traits or can alter their metabolism in response to oxygen shortage to survive or to maintain (Fukao and Bailey-Serres, 2004). Watercress is a semiaquatic crop plant with special adaptations that facilitate the transport of oxygen from the shoot to the roots, particularly the adventitious roots developing exogenously from the stem at the nodes. Some of those roots are able to grow into the medium, particularly in non-aerated conditions, partially replacing the function of the original root system and maintaining normal plant growth. In this study, oxygen depletion promoted the number of nodes with adventitious roots longer than $2 \mathrm{~mm}$. Although this may be an advantage for growing in these conditions, the appearance 

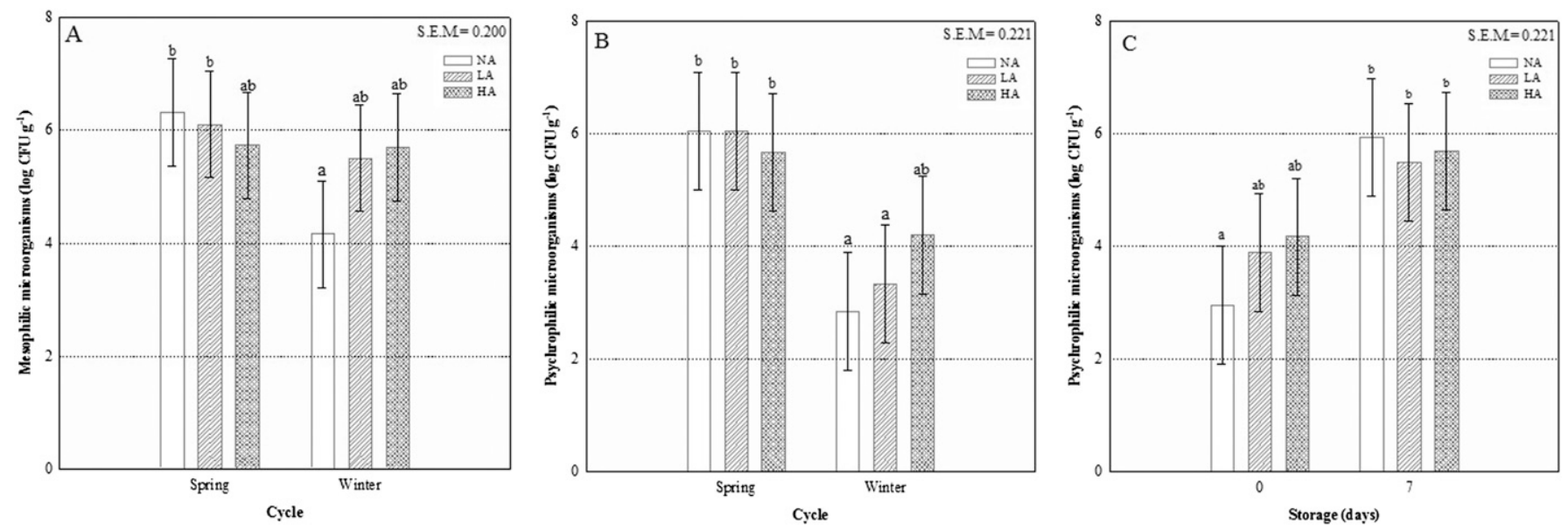

Fig. 2. Effect of the aeration level of the nutrient solution —no aeration (NA), low aeration (LA), high aeration (HA) —on mesophilic (A) and psychrophilic (B) microorganisms in watercress, cultivated in a floating system, either in spring or winter cycles; and the effect on psychrophilic microorganisms (C) at harvest or $7 \mathrm{~d}$ at $5{ }^{\circ} \mathrm{C}$. Values are the mean of three replicates and vertical lines are the least significant difference (LSD) intervals at $P \leq 0.05$. Different letters indicate significant differences $(P<0.05)$.

Table 4. Interaction (cycle $\times$ aeration $\times$ storage time) in the parameters of color [chromaticity $\left(\mathrm{C}^{*}\right)$ and lightness $\left.\left(\mathrm{L}^{*}\right)\right]$ of watercress, cultivated in a floating system, with different levels of aeration of the nutrient solution - no aeration (NA), low aeration (LA), high aeration (HA) - in two crop cycles (spring and winter) stored at $5{ }^{\circ} \mathrm{C}$ for up to $7 \mathrm{~d}$.

\begin{tabular}{lcccccc}
\hline & & \multicolumn{2}{c}{ Chromaticity $^{z}$} & & \multicolumn{2}{c}{ Lightness $^{y}$} \\
\cline { 3 - 4 } Cycle & Aeration & Day 0 & Day 7 & & Day 0 & Day 7 \\
\hline Spring & NA & 21.42 & 29.64 & & 38.24 & 47.19 \\
& LA & 22.42 & 28.19 & & 41.29 & 45.60 \\
& HA & 24.46 & 29.98 & & 42.79 & 47.09 \\
\multirow{3}{*}{ Winter } & & & & & 44.50 & 45.43 \\
& NA & 31.09 & 32.06 & & 42.74 & 44.99 \\
& LA & 32.50 & 31.89 & & 43.53 \\
\hline
\end{tabular}

${ }^{\mathrm{z}} \mathrm{SEM}=0.77 ;$ LSD $=1.79$

${ }^{\mathrm{y}_{\mathrm{SEM}}}=0.81 ; \mathrm{LSD}=1.88$.

LSD $=$ least significant difference.

of these root lowers the product's market value (Smith, 2007).

The aeration treatment had no effect on the yield and growth traits measured (Table 1) showing that watercress is not sensitive to the oxygen depletion. This was especially evident in the spring cycle, where the levels of DO reached in NA conditions were lower as a result of the higher temperatures of the nutrient solution (Fig. 1). In our study, growing season influenced yield and SLA. Among others growth factors, it has been demonstrated that an increase in light levels enhances watercress growth and production (Going et al., 2008; Seelig, 1974). Furthermore, Going et al. (2008) demonstrated that the SLA of watercress decreased linearly along a gradient of increasing light levels, developing thinner leaves in low light conditions. The mentioned results agree with our study, where the spring cycle, with the average DLI 3-fold higher than in winter, produced the highest yield and the lowest SLA.

Among the metabolic adaptations to oxygen deficiency, the results showed that the aeration treatment affected the nitrate, $\mathrm{Ca}^{2+}$, and vitamin $\mathrm{C}$ contents as well as the antioxidant capacity (Table 2). Watercress roots have a high ability to remove nitrate from water, which makes this plant ideal for stripping nitrate from stream water (Vicent and Downes, 1980). In our study, nitrate was accumulated in high concentrations in both cycle experiments (Table 2), which confirms that watercress is a nitrate-accumulating plant (Santamaria, 2006). A lack of aeration in the nutrient solution decreased the nitrate concentration in the winter cycle, which agrees with the results obtained in other species grown in floating systems (Ferrante et al., 2003; Lara et al., 2011; Tesi et al., $2003 \mathrm{~b}$ ). On the other hand, light is one of the main factors influencing nitrate concentration, which increases in the plant tissue under poor light conditions, e.g., in the greenhouse in winter and in green leafy vegetables (Gruda, 2005). In addition, Michalsky et al. (1997) demonstrated that artificial light decreased the nitrate content in watercress grown in an ebb-flow system. In our study, the nitrate concentration (Table 2) in HA conditions was higher in the winter cycle under lower light conditions, confirming the importance of light on its concentration. The oxalate content in the shoots was quite low compared with other leafy species and aeration had no statistically significant effect on the oxalate content.
Usually, low-oxygen solutions have a negative effect on nutrient acquisition by roots because ion uptake by cells is affected by oxygen level. In our study, $\mathrm{K}^{+}$and $\mathrm{Ca}^{2+}$ concentrations decreased under NA conditions in the winter cycle, in agreement with the results of Trought and Drew (1980) who demonstrated that under hypoxic conditions, $\mathrm{K}^{+}$and $\mathrm{Ca}^{2+}$ concentrations fell in the shoots of wheat.

Another physiological response of plants to oxygen depletion stress is the involvement of antioxidant defense mechanism to cope with post-hypoxia stress oxidative (Colmer and Voesenek, 2009). In our experiment, the total antioxidant capacity was higher in NA conditions in both growing seasons and significantly higher in spring when the lack of oxygen was more noticeable (Table 2; Fig. 1). According to Gökmen et al. (2000), phenolic compounds, along with vitamin $\mathrm{C}$, are the major antioxidants of Brassica vegetables as a result of their high content and high antioxidant activity. In our study, the phenolic compounds were unaffected by oxygen stress as antioxidant capacity and vitamin $\mathrm{C}$ were. We assume that the variations in antioxidant capacity were the result of vitamin $\mathrm{C}$ and probably other sources such as glutathione and other phytonutrients, etc., which were not quantified in this study. We found a high level of correlation between the antioxidant capacity and the vitamin $\mathrm{C}$ content (Table 2), as other authors have demonstrated in other baby leaf Brassicacea species (Martínez-Sánchez et al., 2008), confirming a fundamental role of AA in the plant defense system to protect metabolic processes against $\mathrm{H}_{2} \mathrm{O}_{2}$ and other toxic derivatives of oxygen (Shao et al., 2008). The high concentrations of vitamin $\mathrm{C}$ in watercress (Table 2), especially in the spring NA conditions, compared with other salad vegetables (Souci et al., 2008), should be noted, underlining its value as a healthy food for human consumption. The different levels of vitamin $\mathrm{C}$ detected in watercress according to the growing season 
Spring cycle

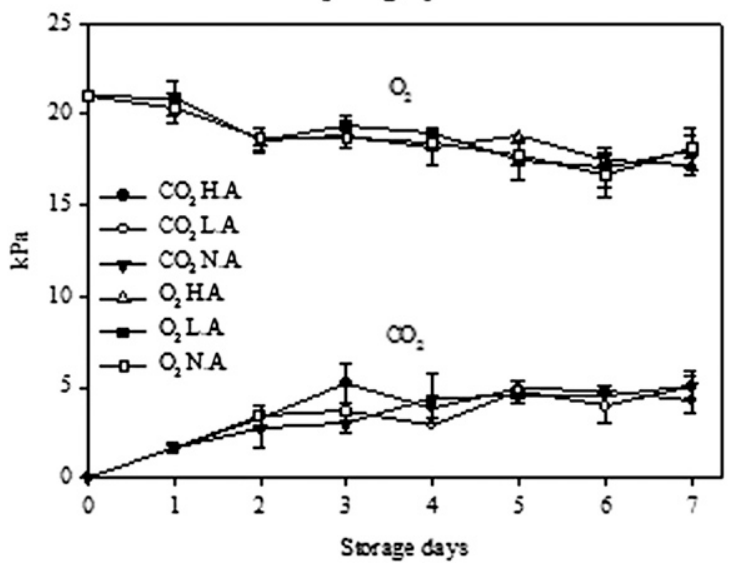

Winter cycle

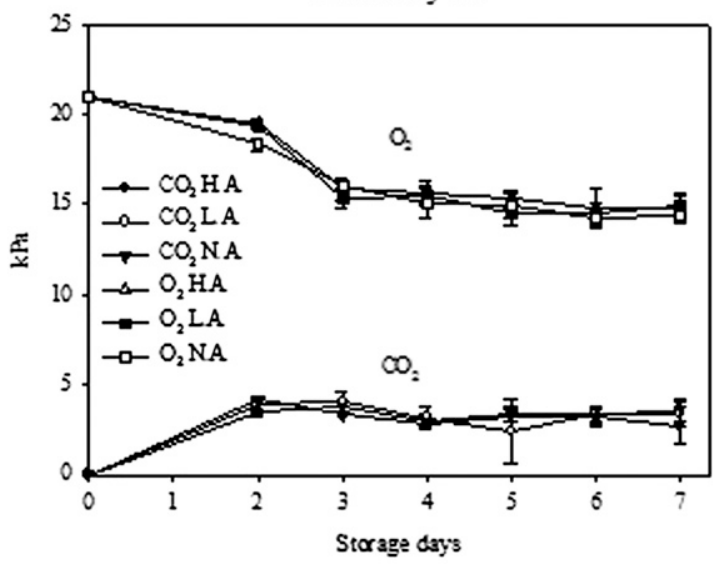

Fig. 3. Influence of the aeration level of the nutrient solution-no aeration (NA), low aeration (LA), high aeration (HA) — on the headspace partial pressure of $\mathrm{O}_{2}$ and $\mathrm{CO}_{2}$ within the polypropylene basket of fresh-cut watercress cultivated in two cycles (spring and winter) and stored for $7 \mathrm{~d}$ at $5^{\circ} \mathrm{C}$. Values are the mean of three replicates $\pm \mathrm{SD}$.

could be the result of light intensity, because in general, the lower the light intensity, the lower the content of AA in plant tissues (Lee and Kader, 2000).

Preharvest treatments of fruits and vegetables are primarily aimed at increasing yields, whereas postharvest storage performance is normally neglected (Workneh and Osthoff, 2010). Weston and Barth (1997) hypothesized that the diversified postharvest responses of fruits and vegetables during storage are in part the result of preharvest cultural practice. Reflecting this, our results indicated that the aeration treatment influenced the microbial population during storage, especially regarding psychrophilic microorganisms (Table 3; Fig. 2C). In NA conditions psychrophiles had increased by Day 7 , which indicates that there was more organic matter available in watercress under non-aerated conditions probably as a result of the physical stress caused by oxygen depletion (probably more microfractures, more dead cells, etc.). However, the number of mesophiles at Day 0 was similar to those at the end of storage because of the temperature $\left(5^{\circ} \mathrm{C}\right)$, which was not ideal for their growth. In winter, the NA conditions led to significantly lower microbial counts $(\approx 4 \log \mathrm{CFU} / \mathrm{g})$ than in spring (Fig. 2A-B), probably as a result of the climatic conditions. The microbial counts in LA and HA conditions in both cycles were similar to those obtained in lamb's lettuces growing in aerated nutrient solutions in a floating system (Manzocco et al., 2011). However, in our study, there were no significant differences between initial and final counts, probably as a result of the small cut surface of the watercress shoots.

Steady-state atmosphere revealed high $\mathrm{O}_{2}$ and low $\mathrm{CO}_{2}$ values (Fig. 3) in the headspace of PP baskets thermosealed with a film of PET + OPP of low permeability (see "Materials and Methods"). However, the respiration rate of watercress is very high (Hardenburg et al., 1986), $\approx 44$ to $49 \mathrm{mg} \mathrm{CO}\left(\mathrm{kg} \cdot \mathrm{h}^{-1}\right)$, which, together with the low gas metabolic permeability of PET + OPP, means that the total $\mathrm{CO}_{2}$ production resulting from respiration was low because the total mass of product within the PP baskets was low as well.

The modified atmosphere packaging (MAP) conditions recommended for watercress are the following: $5 \%$ to $15 \% \mathrm{CO}_{2}$ and $1 \%$ to $5 \% \mathrm{O}_{2}$. However, metabolic gas values obtained in our experiments were quite different from the optimum MAP conditions for this product and global quality ranged from good to excellent. Therefore, the resulted atmosphere was suitable for $7-\mathrm{d}$ storage at $5{ }^{\circ} \mathrm{C}$.

Variations in the color of green leafy vegetables after harvest are a result of high biological variance and heterogeneity of the product at harvest (Løkke et al., 2013). During postharvest senescence, the green chlorophyll pigments are oxidized into colorless substances revealing the yellow carotenoids (Toivonen and Brummell, 2008). Our data showed higher $C^{*}$ (Table 4$)$ at harvest in the winter cycle, which means vivid color than in the spring cycle as a result of the lower light intensity. At Day $7, \mathrm{C}^{*}$ and $\mathrm{L}^{*}$ increased in the spring cycle indicating less chlorophyll and probably as a result of the formation of pheophytin, an olive-colored pigment that is synthesized when chlorophyll loses its bound magnesium atom, which is substituted by hydrogen. More than 50\% conversion of the chlorophyll to pheophytin may occur before a change in color from bright green to olive brown is observed (Lau and Swanson, 2000). Also in winter, L* was higher at Day 7 in LA and HA than in NA conditions, which means bleaching of leaves with storage. This bleaching was not observed by Hinojosa et al. (2013) who denoted a slight decrease in $\mathrm{L}^{*}$ value during storage from $\approx 51$ to 49 after $7 \mathrm{~d}$ at $5{ }^{\circ} \mathrm{C}$, depending on disinfectant treatment.

The overall quality of the watercress at $7 \mathrm{~d}$ of storage was generally good and the aeration treatments had no effect on the same. The mild dehydration problems observed in the winter cycle that led to a lower overall product quality could have been the result of the development of thinner leaves (higher
SLA) under low light conditions and also the differences in the respiration rates (Fig. 3) compared with the spring cycle.

In conclusion, the floating system is a very important preventive tool to obtain cleaner raw material such as watercress as a result of, among other things, the low microbiological contamination. Spring season seemed to be more suitable than the winter season to reach high yield and quality, possibly as a result of high light and temperature conditions available. Thus, plants from the spring cycle in general had higher yield, antioxidant capacity, and $\mathrm{Ca}^{2+}$ and $\mathrm{K}^{+}$contents and lower oxalate content. A lack of aeration slightly improved the quality of the final product, which was richer in vitamin $\mathrm{C}$ and antioxidants and had lower nitrate content.

\section{Literature Cited}

Bonasia, A., G. Conversa, C. Lazzizera, and A. Elia. 2013. Pre-harvest nitrogen and Azoxystrobin application enhances postharvest shelf-life in butterhead lettuce. Postharvest Biol. Technol. 85:67-76.

Brand-Williams, W., M.E. Cuvelier, and C. Berset. 1995. Use of a free radical method to evaluate antioxidant activity. Lebensmittel-Wissenschaft und-Technologie 28:25-30.

Clarkson, G.J.J., E.E. O'Byrne, S.D. Rothwell, and G. Taylor. 2003. Identifying traits to improve postharvest processability in baby leaf salad. Postharvest Biol. Technol. 30:287-298.

Colmer, T.D. and L.A.C.J. Voesenek. 2009. Flooding tolerance: Suites of plant traits in variable environments. Funct. Plant Biol. 36:665-681.

Conte, A., G. Conversa, C. Scrocco, I. Brescia, J. Laverse, A. Elia, and M.A. Del Nobile. 2008. Influence of growing periods on the quality of baby spinach leaves at harvest and during storage as minimally processed produce. Postharvest Biol. Technol. 50:190-196.

Egea-Gilabert, C., J.A. Fernández, D. Migliaro, J.J. Martínez-Sánchez, and M.J. Vicente. 2009. Genetic variability in wild $v s$. cultivated Eruca vesicaria populations as assessed by morphological, agronomical and molecular analyses. Sci. Hort. 121:260-266.

Evans, D. 2003. Aerenchyma formation. New Phytol. 161:35-49. 
Ferrante, A., L. Incrocci, R. Maggini, and F. Tognoni. 2003. Preharvest and postharvest strategies for reducing nitrate content in rocket (Eruca sativa). Acta Hort. 628:153-159.

Fukao, T. and J. Bailey-Serres. 2004. Plant responses to hypoxia-Is survival a balancing act? Trends Plant Sci. 9:449-456.

Going, B., J. Simpson, and T. Even. 2008. The influence of light on the growth of watercress (Nasturtium officinale $\mathrm{R}$. Br.). Hidrobiologia 607:75-85.

Gökmen, V., N. Kahraman, N. Demir, and J. Acar 2000. Enzymatically validated liquid chromatographic method for the determination of ascorbic and dehydroascorbic acids in fruit and vegetables. J. Chromatography 881:309-316.

Gruda, N. 2005. Impact of environmental factors on product quality of greenhouse vegetables for fresh consumption. Crit. Rev. Plant Sci. 24:227-247.

Hardenburg, R.E., A.E. Watada, and C.Y. Wang. 1986. The commercial storage of fruits, vegetables, and florist and nursery stocks. USDAARS Handbook 66:12-62.

Hinojosa, A., A.C. Silveira, M. Ospina, C. Char, C. Sáenz, and V. Escalona. 2013. Safety of ready-to-eat watercress using environmentally friendly sanitization methods. J. Food Qual. 36:66-76.

Kaskey, J.B. and D.R. Tindall. 1979. Physiological aspects of growth and heteroblastic development of Nasturtium officinale under natural conditions. Aquat. Bot. 7:209-229.

Lara, L., C. Egea-Gilabert, D. Niñirola, E. Conesa, and J.A. Fernández. 2011. Effect of aeration of the nutrient solution on the growth and quality of purslane (Portulaca oleracea). J. Hort. Sci. Biotechnol. 86:603-610.

Lau, M. and B. Swanson. 2000. Kinetics of textural and color changes in green asparagus during thermal treatments. J. Food Eng. 45:231-236.

Lee, S.K. and A.A. Kader. 2000. Preharvest and postharvest factors influencing vitamin $\mathrm{C}$ content of horticultural crops. Postharvest Biol. Technol. 20:207-220.

Løkke, M.M., H. Fast Seefeldt, T. Skov, and M. Edelenbos. 2013. Color and textural quality of packaged wild rocket measured by multispectral imaging. Postharvest Biol. Technol. 75:86-95.

Manzocco, L., M. Foschia, M. Tomasi, and M. Maifreni. 2011. Influence of hydroponic and soil cultivation on quality and shelf life of ready-to-eat lamb's lettuce (Valerianella locusta L. Laterr). J. Sci. Food Agr. 91:1373-1380.

Martínez-Sánchez, A., A. Allende, Y. CortésGalera, and M.I. Gil. 2008. Respiration rate response of four baby Brassica species to cutting at harvest and fresh-cut washing. Postharvest Biol. Technol. 47:382-388.

Mattheis, J.P. and J.K. Fellman. 1999. Preharvest factors influencing flavor of fresh fruit and vegetables. Postharvest Biol. Technol. 15:227232 .

Michalsky, F., A. Hanke, and W.H. Schnitzler. 1997. Ertrag und qualität von brunnenkresse im Ebbe/Flut-System. Gemüse 33:575-578.

Nicola, S., G. Tibaldi, and E. Fontana. 2009. Freshcut produce quality: Implications for a systems approach, p. 247-282. In: Florkowski, W.J., R.L. Shewfelt, B. Brueckner, and S.E. Prussia (eds.). Postharvest handling. 2nd Ed. Elsevier Inc. and Academic Press, Amsterdam, The Netherlands.

Palaniswamy, U., R.J. McAvoy, and B. Bible. 1997. Supplemental lighting before harvest increases phenethyl isothiocyanate in watercress under 8-hour photoperiod. HortScience $31: 222-223$.

Rodríguez-Hidalgo, S., F. Artés-Hernández, P. Gómez, F. Artés, and J.A. Fernández. 2010a. Quality changes on minimally processed purslane baby leaves growth under floating trays system. Acta Hort. 877:641-648.

Rodríguez-Hidalgo, S., F. Artés-Hernández, P. Gómez, J.A. Fernández, and F. Artés. 2010b. Quality of fresh-cut baby spinach grown under a floating trays system as affected by nitrogen fertilization and innovative packaging treatments. J. Sci. Food Agr. 90:1089-1097.

Santamaria, P. 2006. Nitrate in vegetables: Toxicity, content, intake and EC regulation. J. Sci. Food Agr. 86:10-17.

Seelig, R.A. 1974. Fruit and vegetable facts and pointers-Watercress. United Fresh Fruit \& Vegetable Association, Washington, DC.

Shao, H.B., L.Y. Chu, Z.H. Lu, and C.M. Kang. 2008. Primary antioxidant free radical scavenging and redox signaling pathways in higher plant cells. Intl. J. Biol. Sci. 4:8-14.

Smith, E.N. 2007. Watercress (Nasturtium officinale) production utilizing brook trout (Salvelinus fontinalis) flow-through aquaculture effluent. Thesis, Davis College of Agriculture, Forestry, and Consumer Sciences at West Virginia University.
Souci, S., W. Fachmann, and H. Kraut. 2008. Food composition and nutrition tables. Medpharm Scientific Publishers, Stuttgart, Germany.

Syed Alwi, S.S., B.E. Cavell, and U. Telag. 2010. In vivo modulation of $4 \mathrm{E}$ binding protein $\mathrm{I}$ (4EBPI) phosphorylation by watercress: A pilot study. Brit. J. Nutr. 104:1288-1296.

Tarazona-Díaz, M.P., J. Viegas, M. Moldao-Martins, and E. Aguayo. 2011. Bioactive compounds from flesh and by-product of fresh-cut watermelon cultivars. J. Sci. Food Agr. 91:805-812.

Tesi, R., A. Lenzi, and P. Lombardi. 2003a. Effect of different $\mathrm{O}_{2}$ levels on spinach (Spinacia oleracea L.) grown in a floating system. Acta Hort. 614:631-637.

Tesi, R., A. Lenzi, and P. Lombardi. 2003b. Effect of salinity and oxygen level on lettuce grown in a floating system. Acta Hort. 609:383-387.

Toivonen, P.M.A. and D.A. Brummell. 2008. Biochemical bases of appearance and texture changes in fresh-cut fruit and vegetables. Postharvest Biol. Technol. 48:1-14.

Tomás-Callejas, A., G.B. Martínez-Hernández, F. Artés, and F. Artés-Hernández. 2011. Neutral and acidic electrolyzed water as novel sanitizers on fresh-cut mizuna baby leaves. Effects on safety and quality attributes. Postharvest Biol. Technol. 59:298-306

Trought, M.C.T. and C. Drew. 1980. The development of waterlogging damage in young wheat plants in anaerobic solution cultures. J. Expt. Bot. 31:1573-1585.

Vicent, W.F. and M.T. Downes. 1980. Variation in nutrient removal from a stream by watercress (Nasturtium officinale R. Br.). Aquat. Bot. 9:221-235.

Visser, E.J.W., T.D. Colmer, C.W.P.M. Blom, and L.A.C.J. Voesenek. 2000. Changes in growth, porosity, and radial oxygen loss from adventitious roots of selected mono- and dicotyledonous wetland species with contrasting types of aerenchyma. Plant Cell Environ. 23:1237-1245.

Visser, E.J.W., R.H.M. Nabben, C.W.P.M. Blom, and L.A.C.J. Voesenek. 1997. Elongation by primary lateral roots and adventitious roots during conditions of hypoxia and high ethylene concentrations. Plant Cell Environ. 20:647-653.

Weston, L.A. and M.M. Barth. 1997. Preharvest factors affecting postharvest quality of vegetables. HortScience 32:812-816.

Workneh, T.S. and G. Osthoff. 2010. A review on integrated agro-technology of vegetables. Afr. J. Biotechnol. 9:9307-9327. 